\title{
Laser photobiomodulation as a potential multi-target anticancer therapy-review
}

\author{
Luis Santana-Blank, Rodríguez-Santana Elizabeth, J esús A Santana-Rodríguez, Karin E \\ Santana-Rodríguez, Heberto Reyes
}

FUNDALAS: Foundation for Interdisciplinary Research and Development, Caracas, Venezuela

Correspondence: Luis Santana-Blank. Address: MUN 1262 Calle Las Flores con Guaraguao, C.C. Carabel PB Local 2 Puerto La Cruz, Anzoátegui, Venezuela. E-mail: luissantanablank@gmail.com

Received: January 21,2013

DOI : $10.5430 /$ jst.v3n2p50
Accepted: February 20, 2013

URL: http://dx.doi.org/10.5430/jst.v3n2p50

\section{Abstract}

Background: Anticancer drugs directed at single specific molecular targets tend to induce transitory responses, followed by relapses. Laser photobiomodulation may offer the possibility of targeting multiple hallmarks of cancer by using fit-for-purpose electromagnetic (EM) energy aiming to restore homeostasis-homeokinesis.

Methods/Principal Findings: A literature search of English-language articles in five databases (Medline, ISI Web of Knowledge, Cochrane, Google Scholar, Scirus) was conducted using search terms relating to cancer (neoplasm, advanced cancer, palliative) in combination with photobiomodulation and/or low-level laser therapy (LLLT) in the period from January 1990 to January 2013. Controlled clinical trials with at least 1 year of follow up and minimum compliance of $90 \%$ were included. Clinical studies evaluating lymphedema, mucositis or pain were also included to illustrate post-LLLT responses to adverse effects of chemo-radiotherapy. In vitro and in vivo studies were considered as preliminary data for clinical trials. Retrieved articles suggest that photobiomodulation can modulate anti-tumor effects and reduce the adverse effects of chemo-radiotherapy. Results are discussed giving particular attention to two mechanistic proposals with potential anticancer applications, photo-infrared pulsed biomodulation (PIPBM) and water oscillator (WO).

Conclusions/Significance: Translational research with laser photobiomodulation as a multi-target (multi-hallmark) therapy in cancer and other complex diseases appears warranted.

\section{Key words}

Photobiomodulation, Low level laser therapy, Homeostasis/homeokinesis, Hallmark of cancer, Warburg effect, Water dynamics

\section{Introduction}

It has been proposed that the hallmarks of cancer consist of biological capabilities acquired during the multistep development of human tumors, which taken as principles, allow rationalizing the complexities of neoplastic disease ${ }^{[1-2]}$ These hallmarks include sustaining proliferative signaling, evading growth suppressors, resisting cell death, enabling replicative immortality, inducing angiogenesis, activating invasion and metastasis, reprogramming energy metabolism and evading immune destruction. Myriad hallmark-targeting cancer drugs have aimed at single specific molecular targets, 
with a view to minimizing nonspecific toxicity. However, "clinical responses have generally been transitory, being followed by almost-inevitable relapses" ${ }^{[1]}$.

The acquisition of cancer hallmarks is intricately linked and made possible by the tumor microenvironment (TME). The TME has been described as consisting of cells, soluble factors, signaling molecules, extracellular matrix, and mechanical cues that can promote neoplastic transformation, support tumor growth and invasion, protect the tumor from host immunity, foster therapeutic resistance, and provide niches for dormant metastases to thrive ${ }^{[3]}$. Tissue microenvironments and peripheral systems that control cancer are, thus, increasingly viewed as keys to cancer development and future treatments ${ }^{[4]}$. Anticancer therapies should then no longer aim at single molecular targets to kill cancer cells, but at re-establishing normal tissue microenvironments by promoting homeostasis-homeokinesis ${ }^{[4-7]}$.

A common thread linking these perspectives in oncology and the field of photobiomodulation may be the possibility of using fit-for-purpose electromagnetic (EM) energy to restore tissue homeostasis-homeokinesis for multi-target disease reversal, a micro-environment effect that comprises and extends the Warburg effect previously discussed ${ }^{[8]}$ This review updates and expands this discussion based on recent clinical and preclinical results on the potential application of photobiomodulation in the treatment of solid tumors. In particular, it explores whether laser photobiomodulation may hold potential as a multi-target (multi-hallmark) therapy in cancer and other complex diseases ${ }^{[9-12]}$.

\section{Background}

Shortly after the first working laser was built by T. Maiman in 1960, P. McGuff et al., at Tufts-New England Medical Center in Boston, reported the results of experiments performed with ruby laser applied directly on malignant tumors such as melanomas. They concluded, as cited by L. Hode that, laser energy has a selective effect on certain malignant tumors, resulting in their progressive regression and ultimate dissolution ${ }^{[13,14]}$. In the same period, but half across the world at Semmelweis University in Hungary, E. Mester, as told by Hamblin, "wanted to test if laser radiation might cause cancer in mice ${ }^{[15]}$. He shaved the dorsal hair, divided them into two groups and gave a laser treatment with a low powered ruby laser $(694 \mathrm{~nm})$ to one group. They did not get cancer, and to his surprise the hair on the treated group grew back more quickly than the untreated group." These early experiences exemplify one of the main characteristics of light. Over the following decades, it has been found that light can stimulate or suppress (i.e., modulate) a growing list of genes, oncogenes, cellular proteins, cytokines, cytochrome oxidase ( $\mathrm{CcO}$ ), nitric oxide (NO), reactive oxygen species (ROS), as determined by signal parameters and cell characteristics ${ }^{[16,17]}$. However, until recently, emphasis on the stimulatory potential of certain light parameters on in vitro tumor cells ${ }^{[18]}$ and concern about the poor quality of some reports with low-powered lasers stifled investigations into possible anti-cancer applications. However, there is increasing evidence that low-energy lasers of certain characteristics may be able to control subtle, yet powerful mechanisms that could help resolve one of the most intractable problems in the treatment of cancer and other complex diseases: the modulation of apoptosis ${ }^{[2,9]}$.

\section{Mechanistic foundations}

Eighty years ago, O. Warburg found that most cancer cells tend to rely on anaerobic forms of energy generation such as glycolysis even in the presence of sufficient oxygen for mitochondrial phosphorylation, a phenomenon known as the Warburg effect ${ }^{[19]}$.

Warburg further identified enzyme $\mathrm{CcO}$ as responsible for the last critical step of respiration in mitochondria. Healthy and diseased cells often use $\mathrm{NO}$ to block respiration by binding to $\mathrm{CcO}$ instead of oxygen as part of a complex signaling process ${ }^{[20]}$. Cancer requires this system to go awry. Signaling pathways implicated in proliferation, notably the phosphoinositide 3-kinase (PI3K) pathway, regulate metabolic pathways that incorporate nutrients into biomass ${ }^{[21]}$. Cancer-related mutations enable tumor cells to acquire and metabolize nutrients in a manner conductive to proliferation. 
Remarkably, low-energy pulsed light can displace $\mathrm{NO}$ (freeing the site for oxygen to bind to $\mathrm{CcO}$ again), modulate inositol phosphate via water dynamics in cell membranes ${ }^{[22]}$ and exert other striking effects ${ }^{[23]}$.

Laser photobiomodulation, also known as low-level laser therapy (LLLT), consists of the use of red to near infrared (NIR) monochromatic or quasi-monochromatic laser light to induce primarily photochemical and photophysical effects. Photobiomodulation is a non-linear process that induces a biphasic response described by the Arndt-Schultz (A.S.) curve, which shows that weak stimuli can excite physiological activity while strong stimuli can inhibit it as documented by the concentration of ROS ${ }^{[24,25]}$. Over the last decades, progress has been made toward unmasking primary and secondary mechanisms of photobiomodulation ${ }^{[26,27]}$.

Yet, despite a wealth of substantiated reports, controversy around photobiomodulation has remained in part because (a) experimental reproduction of effects has not always been observed, especially for some unsupported reports, and (b) due to theoretical objections that very small field magnitudes sometimes reported seem to be below allowed thermal noise (1/f). Indeed, a core problem concerning the therapeutic effects of low-energy light (as well as other weak EM signals) is the sensitivity of cells in relation to signal to noise ratios. For bio-effects to be positive, EM signals must fulfill target dielectric properties and induce sufficient voltage to be detectable above thermal noise ${ }^{[28]}$. Moreover, it is the combination of signal and receptor characteristics what determines biological outcome, which is usually optimal for only one set of conditions ${ }^{[28]}$.

Figure 1. Simplified diagram of upstream components of the PIPBM mechanism. Outer ring: Electromagnetic energy is transmitted through aqueous media to target tissues in accordance with the second law of thermodynamics to induce deterministic as well as non-fully deterministic effects, which are regulated by metabolic control levels. Inner circle: Energy from multiple IPLD terminals is captured by micro- (e.g., $\mathrm{H}_{2} \mathrm{O}$ and $\mathrm{CO}_{2}$ ) and macro- (e.g., vascular system) antennas. Energy is transported to biopolymers at two different times by water and biological liquid crystals (LCs) in the cell's lipid bilayer. As LCs, cellular membranes are particularly sensitive to pulsed electromagnetic fields (PEMFs) and behave as transistors that transmit energy to molecular motors and ion pumps causing a cascade of biochemical, biomechanical, and metabolic effects. On the other hand, the enhanced structuring of water in the solvation shell of molecules by the IPLD favors the physiologic activity of network proteins. This effect is reinforced by the activation of open-state dynamics, which induces changes in DNA translation and replication that are consistent with reported reductions in chromosomal aberrations. Arrows signal the flow of IPLD energy. [Ref 31. CMary Ann Liebert, Inc., 2005].

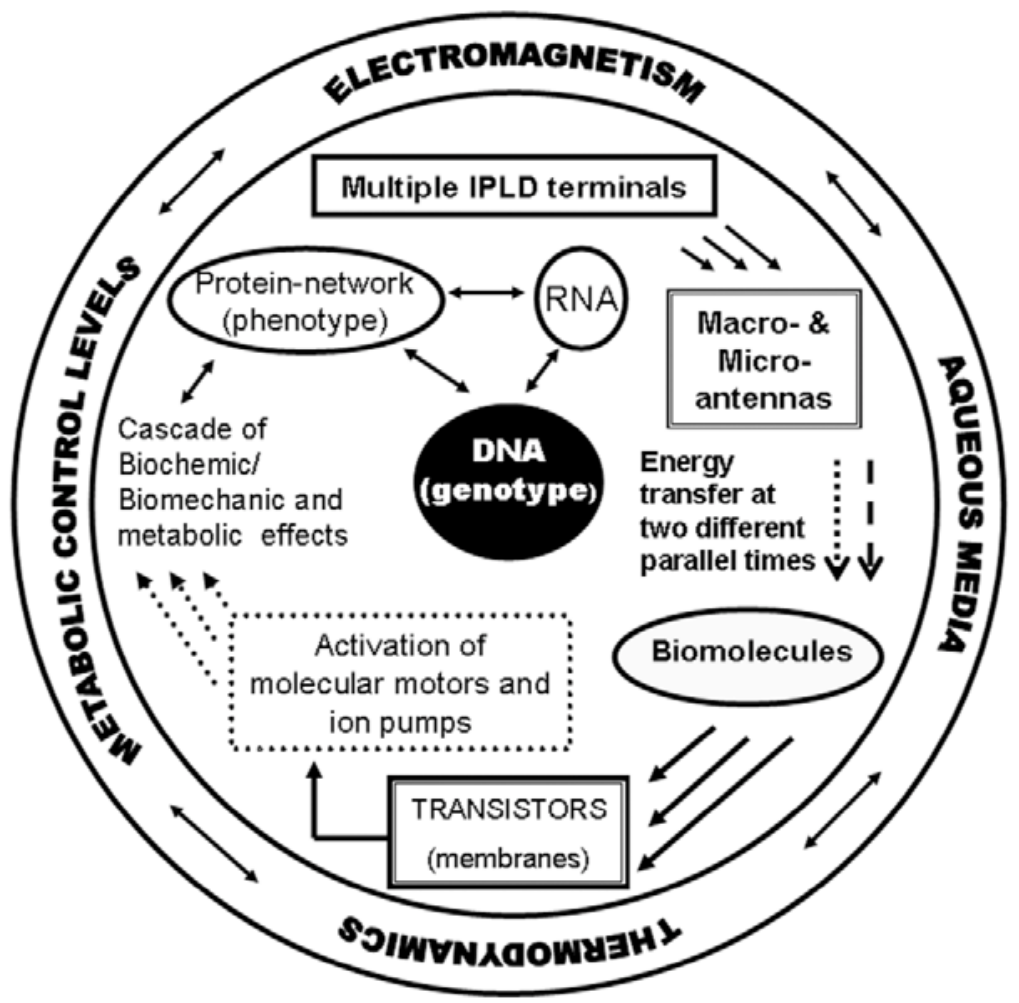

In addition, it has become apparent that, while NIR photo-biological effects have been ascribed primarily to light absorption by $\mathrm{CcO}$ and to the liberation of a number of reactive species, including $\mathrm{ROS}, \mathrm{NO}$, and $\mathrm{H}_{2} \mathrm{O}_{2}$, other photo-acceptors may be at play ${ }^{[29]}$. In that respect, a role for water as an oscillator in photobiomodulation has further been proposed and documented ${ }^{[30]}$. Previously, the cellular and molecular bases of an original mechanism for non-invasive, selective, long-range, energy supplementation termed Photo-Infrared Pulsed Bio-Modulation (PIPBM) were presented (Figure 1) ${ }^{[31]}$. PIPBM complements the classic LLLT photo-biological hypothesis (known to follow primarily ATP- 
dependent pathways) and documents novel ATP-dependent and ATP-independent pathways for external energy supplementation through a proposed water oscillator (WO) ${ }^{[30]}$, which can be photo-induced by absorption of NIR light or adsorption of red light ${ }^{[30,31]}$. Water dynamics are postulated to provide a separate pathway for light absorption and transportation, complementing and facilitating $\mathrm{CcO}$ energy transfer for increased efficiency in ATP production.

ATP is a key signaling molecule connected to the P1 and P2 family of specific receptors, of growing importance in cancer and other complex diseases ${ }^{[32-34]}$. In addition, ATP in of itself may be a potential cancer-fighting tool. Rapaport ${ }^{[34-41]}$ first described the tumor killing effect of ATP in 1983. Since then, research has shown that ATP can inhibit growth in prostate, breast, colorectal, ovarian, and esophageal tumors as well as melanomas. ATP signaling appears to act in part promoting tumor cell suicide and in part fostering differentiation, which slows tumor cell proliferation ${ }^{[41,42]}$. Thus, increased ATP production through PIPBM ${ }^{[31]}$ and WO ${ }^{[30]}$ water-driven pathway, along with the classic LLLT energy transfer mechanism, may hold significant potential for the treatment of tumors in accord the clinical studies described below.

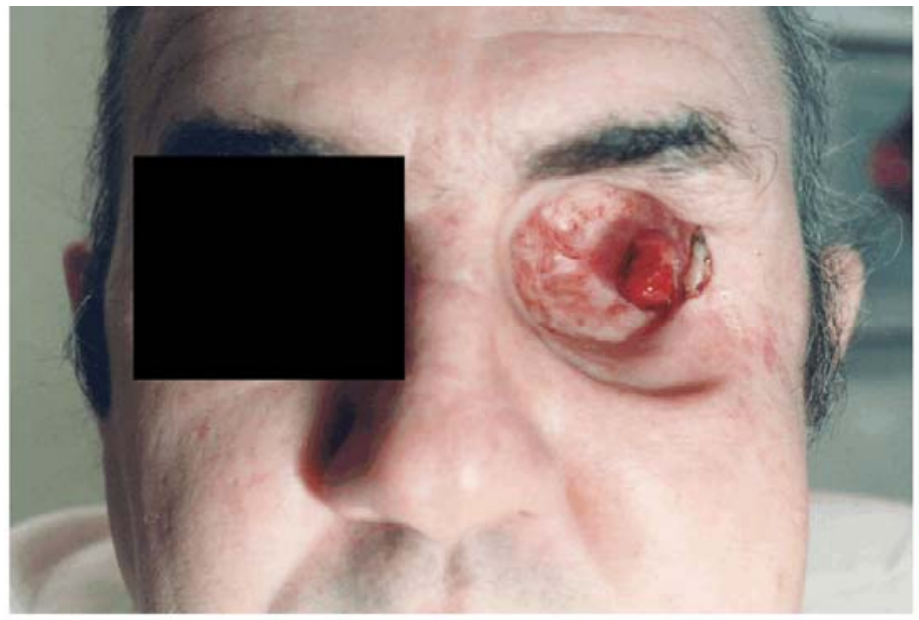

(a)

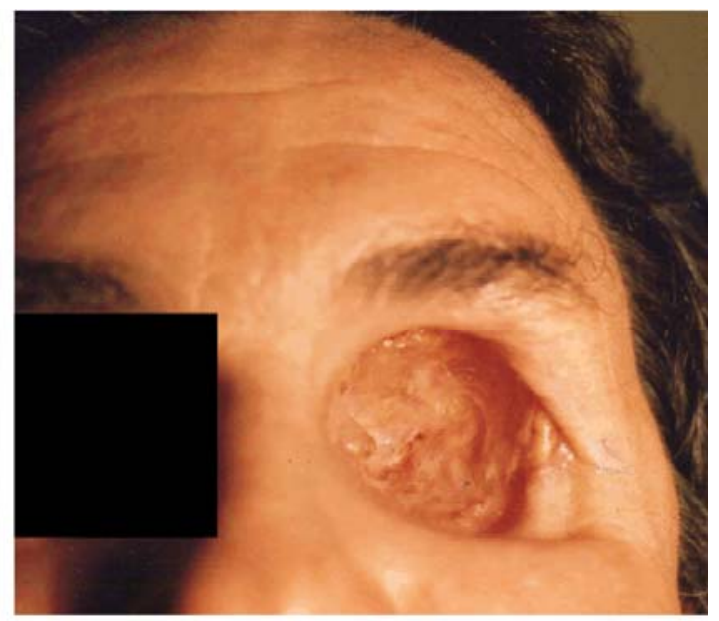

(b)

Figure 2. Pictures of a 45 year old patient with malignant papillary meningioma.

(a) Pre-IPLD treatment image shows metastasis on outer section of the left supra-orbital region and highly recurrent intra-orbital metastasis on the zygomatic region and greater sphenoid wing of the left lateral orbital wall. (b) After IPLD-treatment and local metastectomies recurrence ceased. Note wound healing effect on tissue covering previously exposed orbital margin of the zygomatic bone, and change in hair color and volume.

In solid tumors, ATP and its P- and A-type receptors jointly with inositol pyrophosphates (which regulate ATP concentration by controlling GCR1 factor) have primordial roles. Photobiomodulation may activate and modulate the production of ATP, GTP, AMPK and inositol pirophosphates P7-P8, not only through the respiratory chain but also through absorption and transportation of IR light by water ${ }^{[30,43-48]}$. Among other reasons, this is important as AMPK activity opposes tumor development, and its loss has been shown to foster tumor progression in part by regulating cellular metabolic pathways that support cell growth and proliferation ${ }^{[49]}$.

Research supports that $\mathrm{CcO}$ is a key photo-acceptor of red and NIR light ${ }^{[50,51]}$ in accord with reports of increased electron transfer in purified $\mathrm{CcO}$, higher mitochondrial respiration and ATP synthesis in isolated mitochondria ${ }^{[52]}$ and up-regulation of $\mathrm{CcO}$ activity in cultured neuronal cells following LLLT ${ }^{[53]}$. Increased ATP levels and electrical charge across the mitochondrial membrane have been found to be followed by a concerted shift in the activity of more than 110 genes $^{[54,55]}$. LLLT may also stimulate the upregulation of genes coding for subunits of enzymes involved in complexes I and IV and ATP synthase ${ }^{[56]}$. 
Figure 3. Raw microdensitometry image post IPLD treatment of cheek metastasis of patient with malignant papillary meningioma.

Red tones relate to regions with high water content resulting from photo-induced cellular death. Blue shades correspond to active tumor areas. Wide divide partially separating the image of the tumor is in agreement with described loss of cellular adhesion suggesting microscopic effects of anoikis. Case 1 of Figure 4 shows the corresponding Microdensitometry of T2-weighted MRI.

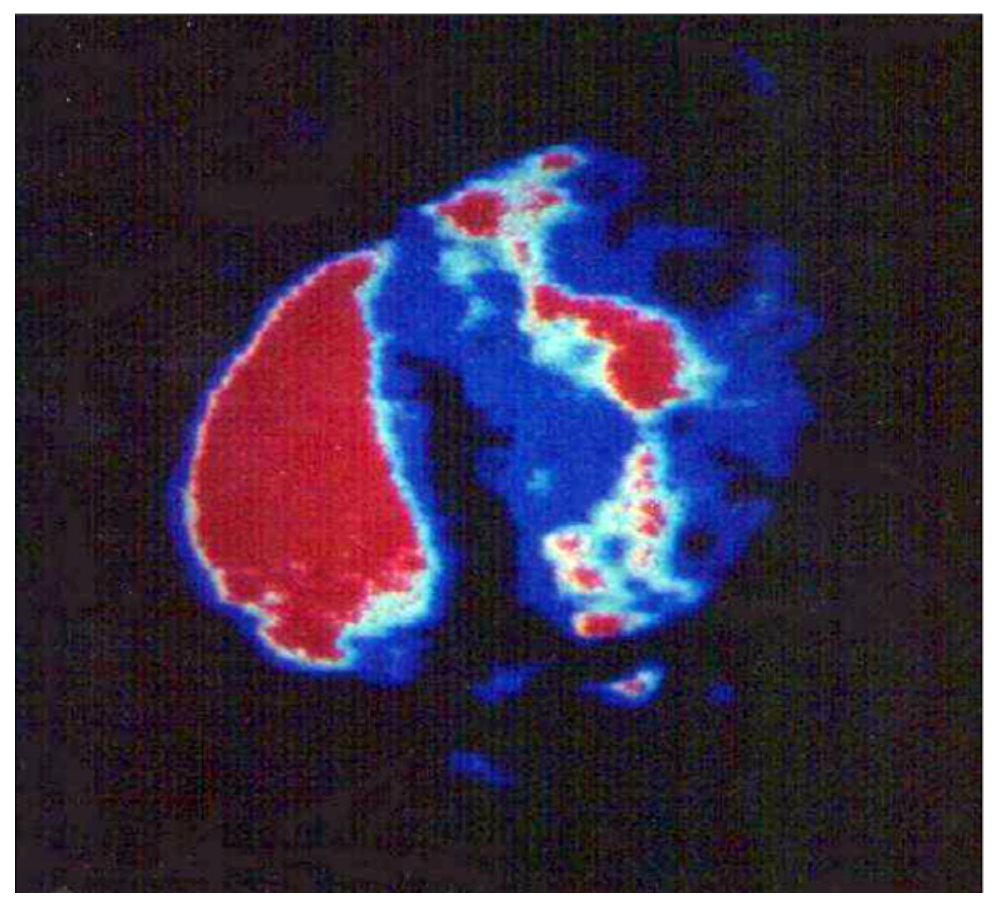

In addition, the above-referred PIPBM and WO mechanism may support ATP-independent effects over ion pumps, molecular motors, and the chemical response rate of biomolecules such as nucleic acids and proteins. Indeed, it has been found that pulsed light can substitute ATP to power cellular work by modulating Brownian motion ${ }^{[30,42]}$. Among other reasons, this is significant because cancer and many neurodegenerative diseases share age-related and metabolic disorderdependent damage of cellular energy and transport processes that are mostly caused by ROS stress. Theoretical ${ }^{\text {[57-59], }}$ experimental ${ }^{[60,61]}$ and clinical ${ }^{[8-12]}$ studies further suggest that PIPBM and WO may enhance physiologically reparative processes in a noninvasive, non-toxic, systemic, and selective manner through the activation and modulation of chaotic dynamics in water. These in turn lead to local and long-distance (systemic) effects with many potential applications in medicine.

\section{Method}

\section{Literature search}

Five databases (Medline, ISI Web of Knowledge, Cochrane, Google Scholar, and Scirus) were searched, from January 1990 to January 2013, using terms relating to cancer (neoplasm, advanced cancer, palliative) in combination with photobiomodulation and/or LLLT. Controlled clinical trials with at least 1 year of follow up and a minimum 90\% compliance were included. Clinical studies evaluating lymphedema, mucositis or pain were also obtained to illustrate post-LLLT responses to adverse effects of chemo-radiotherapy. In vitro and in vivo studies were considered as preliminary data for clinical trials. Non-English publications were excluded because of the difficulty in obtaining, assessing and comparing them against other retrieved studies.

\section{Results}

\subsection{Clinical results}

Clinical data from a controlled human trial have been reported with a first approach at PIPBM using an infrared pulsed laser device (IPLD) ${ }^{[62]}$ (904 $\mathrm{nm}$ pulsed at $3 \mathrm{MHz}$ with $35 \mathrm{~mW}$ of power) using a $10 \mathrm{~mm}$ spot size (top-hat), under a 
one-dose, one-procedure design (field intensity / power density, $4.5 \times 10^{4} \mathrm{~mW} / \mathrm{cm}^{2}$ ), radiant exposure was fractionated and treatment administered during daytime. A phase I trial in patients with advanced neoplasias demonstrated that the IPLD was safe for clinical use and improved performance status and quality of life ${ }^{[9]}$. Antitumor activity was observed in $88.23 \%$ of patients with a 10-year follow-up (Figure 2) ${ }^{[9]}$. T2-weighted MRIs showed increased water content in tumor heterogeneities preceding tumor-volume reduction and therapeutic anticancer effects ${ }^{[9,11]}$. Figure 3 is an example of high water content resulting from photo-induced cellular death in a sample raw-microdensitometry image. Figure 4 depicts the corresponding microdensitometric analysis of T2-weighted MRIs, indicative of early anti-cancer response, which precedes the reduction of tumor volume. Structural, kinetic, and thermodynamic implications of these changes in water dynamics have been analyzed at the tissue, cell, and interstitial levels ${ }^{[11]}$. In addition, a tumor characterization algorithm showed displacement of treated tumors within a described malignancy relaxation rate window (Figure 5) ${ }^{[63,64]}$. Figure 6 shows the sequential histological analysis of tissue samples from a colon ADC (TNM IV) patient in the phase I trial. Significant selective photo-activation of apoptosis, anoikis and necrosis and cytomorphologic modifications, such as reduced size, increased roundness and increased vacuoles, were found in neoplastic cells, but not in peripheral tissues ${ }^{[6,10]}$.

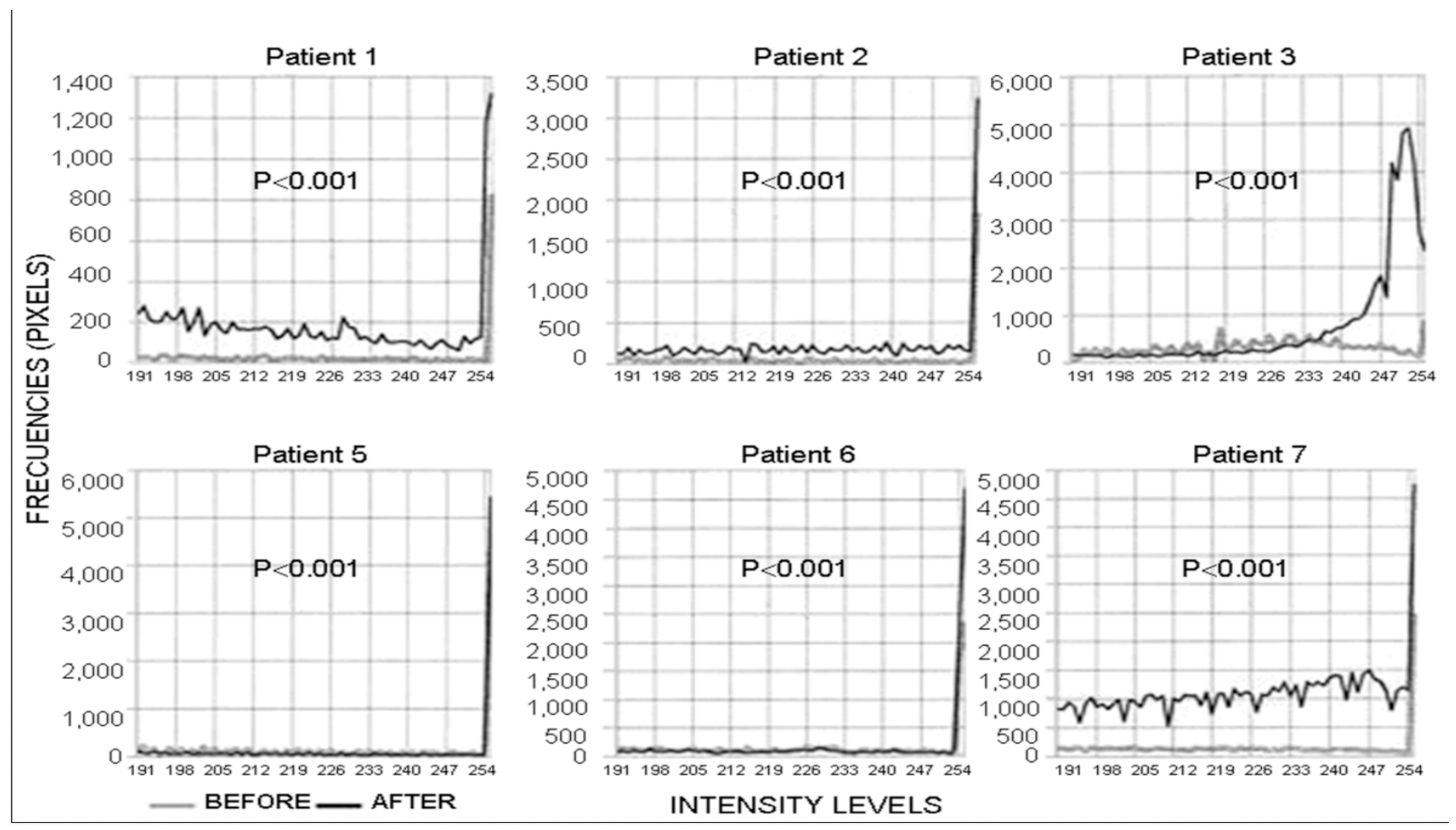

Figure 4. Microdensitometry of T2-weighted MRIs. Curves show early evidence of IPLD-induced anti-cancer response in the form of a significant increase in the water content of tumor heterogeneities before measurable reduction in tumor volume after IPLD-photo-induced tumor cell death. Significant post-treatment values for six patients, with intensity levels ranging from 191 to 255, are shown [For details, see Ref. 11].

Monitoring further showed activation of $\mathrm{CD} 25^{+}$cells in both surviving and deceased patients, and modulation (initial increase and later decrease) of CD4 CD45 RA ${ }^{+}$, TNF- $\alpha$, and soluble IL-2 receptor (sIL-2R) in surviving patients ${ }^{[12]}$ - in agreement with subsequent reports ${ }^{[65]}$. As recently argued, to be effective, cancer immunotherapy must co-activate $\mathrm{CD} 4^{+}$ $\mathrm{T}$ cells, suggesting that future immunotherapy trials should aim at activating $\mathrm{CD} 4^{+} \mathrm{T}$ helper cells in an antigen-specific manner ${ }^{[66]}$. IL-2 has also been associated with homeostatic balance between the regulatory and conventional $\mathrm{CD} 4^{+} \mathrm{T}$ cell compartments during peripheral $\mathrm{T}$ cell reconstitution in cancer ${ }^{[67]}$. In addition, studies suggest pro-tumorigenic roles for 
immune cell subsets linked to cancer-associated inflammation. Thus, if such cells could be reprogrammed, as suggested by the above photobiomodulation results, it may be possible to counteract chronic, cancer-promoting, inflammation ${ }^{[68]}$.
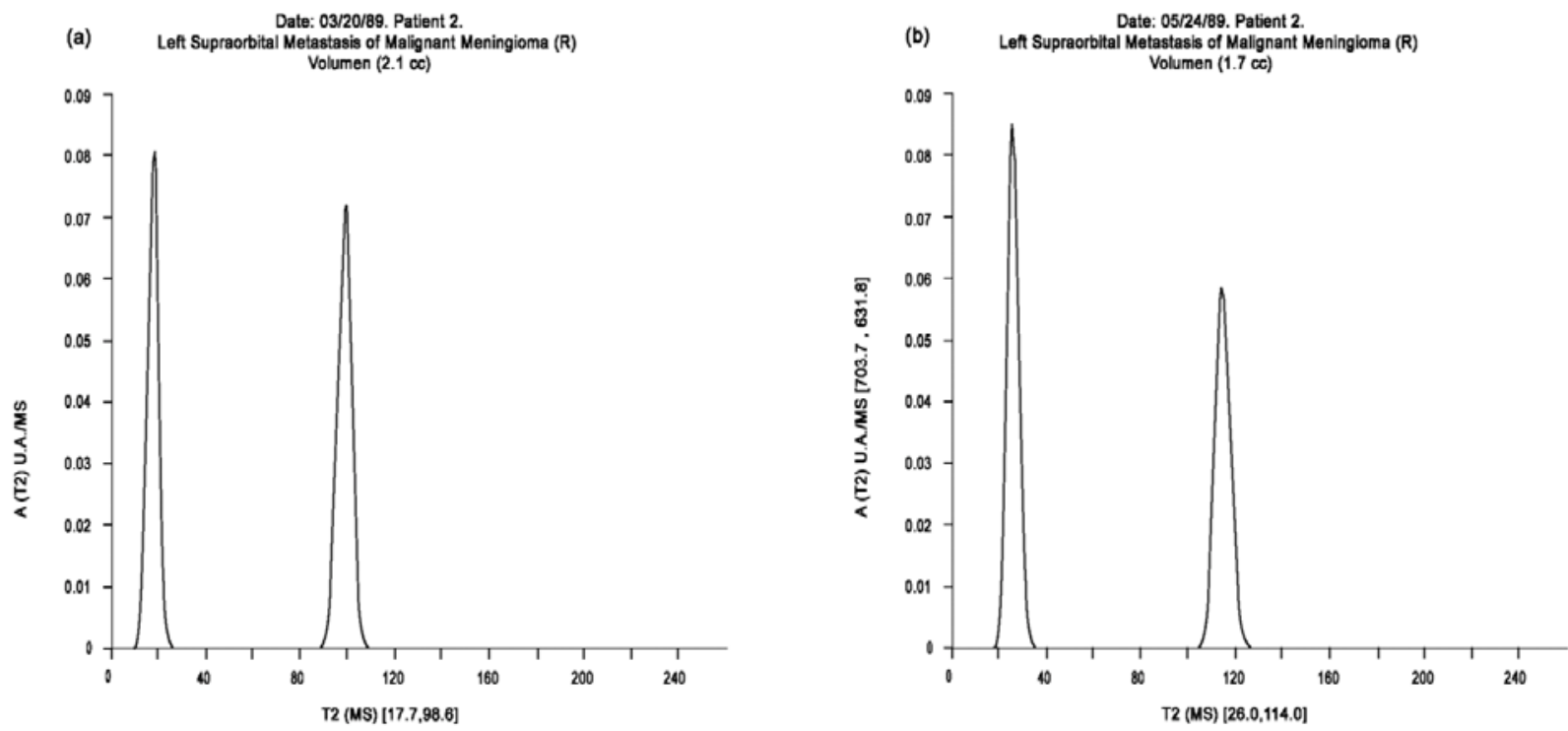

Figure 5. Results of an algorithm for tumor characterization by analysis of transversal relaxation rate distribution. Curves show the evolution over two months of a recurrent left supra-orbital metastasis of a patient with malignant papillary meningioma [Patient 2, in Ref. 9]. (a) The second curve from the left shows mean weighted T2 times inside the proposed neoplastic window (90 to $120 \mathrm{~T} 2 \mathrm{~ms}$ ). (b) The second curve from the left remains in the aforementioned window, but shows a notable rightward shift toward longer T2 values. The first curve on both graphs shows a lack of major changes in the water diffusion of the solvation shell of biopolymers and macromolecules outside the malignancy window (short times). A sharp shift in the curves inside the malignant window can be observed, indicating increased water diffusion associated to higher cell death as a result of IPLD treatment (longer times). Over the period, tumor volume decreased from $2.1 \mathrm{cc}$ to $1.7 \mathrm{cc}(\sim 20 \%)$. [Images courtesy of Rafael Martin PhD. School of Physics, Faculty of Science, Universidad Central de Venezuela]

Figure 6. Sequential analysis of tissue samples from Colon ADC patient in phase I trial.

(a) Microscopic view $(40 \times)$ of sample at Time 0 (pre-IPLD treatment). (b) \& (c) Microscopic views (40× and $100 \times$, respectively) of surgical specimens at Time I (2 months of IPLD treatment). Increased apoptosis and necrosis, reduced cell size, and changes in the shape of neoplastic cells and tumor architecture can be observed; a more cracked pattern caused by decreased inter-cellular adhesion is noticeable. (d) \& (e) Microscopic views $(100 \times)$ of tissue sample at Time II (6 months of IPLD treatment). Neoplastic cells are smaller and rounder, there is rupture of the nucleus and cytoplasm, and cytoplasmatic and nuclear vacuoles are visible.
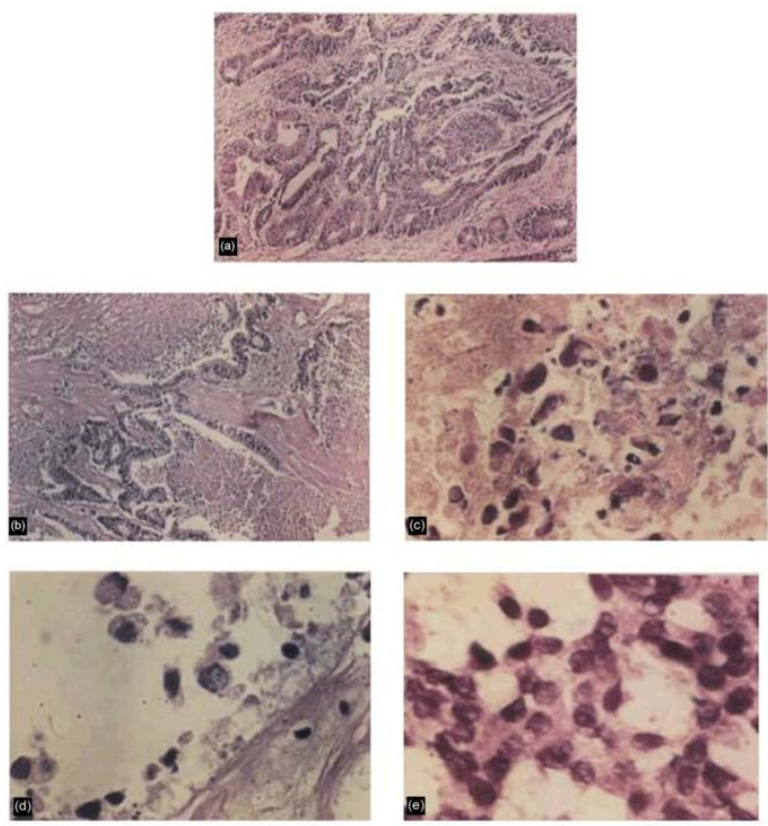
As an important side note, it must be noted that clinical experiences have been reported in Russia and Easter Europe ${ }^{[69,70]}$ but given they appear in non-English language papers, they could not be evaluated and included in this review.

\subsection{Pre-Clinical results}

The above clinical results are in agreement with independent reports from groups in Russia ${ }^{[50,71]}$, United Kingdom ${ }^{[21,72]}$, China ${ }^{[73,74]}$, Japan ${ }^{[75]}$, United States and elsewhere ${ }^{[9,76-79]}$, supporting the premise that low-energy lasers can modulate antitumor effects, in contrast with long-held views ${ }^{[80]}$. For instance, Karu ${ }^{[50]}$ has proposed reconsidering the use of LLLT to treat tumors, citing its capacity to modulate ATP signaling, which can promote tumor cell suicide as discussed above and in a manner consistent with above clinical results ${ }^{[8-12]}$. On the other hand, basic and experimental investigations reported by Lane ${ }^{[72]}$, Moncada ${ }^{[21]}$ (Warburg effect) and Burnstock ${ }^{[81]}$ (ATP signaling), emphasize the ability of light to release $\mathrm{NO}$ from $\mathrm{CcO}$ as a way to modulate apoptosis in cancer and degenerative diseases. ATP signaling related to purinergic receptor-mediated effects in high-grade bladder cancer has also been documented ${ }^{[82]}$.

In addition, a comparative study on the metabolic response of non-confluent and confluent human malignant brain cancer cells to He-Ne laser exposure found evidence of laser-enhanced cellular $\mathrm{H}_{2} \mathrm{O}_{2}$ production and laser-induced bystander effect, suggesting an important role for light-enhanced cellular $\mathrm{H}_{2} \mathrm{O}_{2}$ generation to yield photo-bio-modulatory effects locally and at a distance ${ }^{[31]}$ in accord with research by Wentworth, et al. ${ }^{[83]}$ and with the interpretation of the above clinical results ${ }^{[9]}$. LLLT has been also found to activate and modulate NF-kB via generation of ROS. Thus, LLLT may not only enhance mitochondrial respiration, but activate the redox-sensitive transcription factor NF-kB by modulating ROS as signaling molecules ${ }^{[84]}$.

Recent studies suggest a role of NF-kB in colorectal cancer (CRC) etiology ${ }^{[85]}$ and a physiologic role of NF-kB in protecting cells from apoptosis can help explain the pathologic activation of NF-kB in multiple human cancers ${ }^{[86]}$. Wang, et al. ${ }^{[75]}$ have showed that low-power laser irradiation may induce apoptosis of human lung adenocarcinoma cells (ASTC-a-1). Dong-Liang, Timon Liu and Hua reported that a diode $808 \mathrm{~nm}$ GaAlAs continuous wave laser has an inhibitory effect on the proliferation of human hepatoma cells line HepG2 and J-5 ${ }^{[87,88]}$. In addition, Sommer, et al. proposed the use of laser photobiomodulation to promote the uptake of chemotherapeutic agents in cancer cells, given an observed transmembrane convection mechanism that exploits the effect of moderately intense red laser light on the density and viscosity of nanoscopic interfacial water layers (IWL) in the cell- forcing cancer cells to uptake high doses of cytostatic drugs in a short time ${ }^{[89]}$.

In agreement with the modulating properties of light, evidence also suggests that certain light parameters may cause tumor cells to proliferate. For instance, Pinheiro, et al. reported that irradiation with 670-nm laser light applied at doses between 0.04 and $4.810(4) \mathrm{Jm}(-2)$ could significantly increase proliferation of laryngeal cancer cells ${ }^{[90]}$. Similarly, Frigo, et al. argued that LLLT Irradiation should be avoided over melanomas, as the combination of high irradiance $\left(2.5 \mathrm{~W} / \mathrm{cm}^{2}\right)$ and high dose $\left(1,050 \mathrm{~J} / \mathrm{cm}^{2}\right)$ significantly increases melanoma tumor growth in vivo ${ }^{[91]}$.

\section{Palliative care}

Studies suggest that LLLT may be effective in reducing lymphedema in a clinically meaningful way for some women including a potential decrease in fibrosis, stimulation of macrophages and the immune system, and have a possible role in encouraging lymphangiogenesis ${ }^{[92,93]}$. LLLT was effective in reducing grade 3 or 4 oral mucositis and in reducing radiotherapy interruptions in these head and neck cancer patients treated with concurrent chemo-radiation (CRT), which may translate into improved CRT efficacy and tolerance ${ }^{[94-96]}$.The most important benefit for Nes and Posso was considered to be the value for the patients of better and quicker treatment with a drastic reduction in painful mucositis ${ }^{[97]}$. It has also been argued that LLLT may be given for pain and other symptoms relief during the terminal stages of the illness with the consent of both the patient and consultant involved ${ }^{[98]}$, and it is expected that LLLT will soon become part of routine oral supportive care in cancer ${ }^{[99]}$ 


\section{Conclusion}

The results discussed suggest that, by supplying external EM energy within parameters fit to power and modulate biological systems, photobiomodulation may help restore homeostasis-homeokinesis, inducing physiologically reparative effects for disease reversal in cancer and other complex diseases with minimal, if any, adverse effects, and with potentially marked improvements in quality of life - even in patients with advanced neoplasms. A major conduit for such effects must lie in the activation and modulation of central physiological energy pathways and ATP-independent energy mechanisms. As discussed, photobiomodulation may activate and modulate the production of ATP, GTP, AMPK and inositol pirophosphates P7-P8, not only through the respiratory chain but also through absorption and transportation of IR light by water ${ }^{[6,30,100]}$. This suggests a pathway back to tissue homeostasis-homeokinesis through the reestablishment and the enactment of physiologically reparative mechanisms in cancer and other complex diseases. More incontrovertible evidence from pre-clinical studies as well as randomized controlled clinical trials and greater understanding of light-matter interactions should lead to translational progress. Together these should allow photobiomodulation to make the final leap from the lab to the patients' bedside as a potentially safe and effective multi-target anticancer therapy, potentially amenable for use with other therapies or as a stand-alone approach.

\section{Competing interests}

The author(s) declare that they have no competing interests.

\section{Acknowledgment}

The authors thank Luis R. Santana-Rodríguez for technical assistance. Work supported by Fundalas, Foundation for Interdisciplinary Research and Development.

\section{References}

[1] Hanahan D, Weinberg RA. Hallmarks of Cancer: The Next Generation. Cell. 2011; 144: 646-74. http://dx.doi.org/10.1016/j.cell.2011.02.013

[2] Hainaut P, Plymoth A. Targeting the hallmarks of cancer: towards a rational approach to next-generation cancer therapy. Curr Opin Oncol. 2013; 25: 50-51. http://dx.doi.org/10.1097/CCO.0b013e32835b651e

[3] Swartz MA, Lida N, Roberts EW, Sangaletti S, Wong MH, Yull FE, et al.Tumor microenvironment complexity: emerging roles in cancer therapy. Cancer Res. 2012; 72: 2473-80. http://dx.doi.org/10.1158/0008-5472.CAN-12-0122

[4] Prendergast GC. Perspectives on Emerging Trends in Cancer Research. Cancer Research. 2011; 71: 2027-2028. http://dx.doi.org/10.1158/0008-5472.CAN-11-0427

[5] Santana-Blank L, Rodríguez-Santana E, Santana Rodríguez KE. Concurrence of emerging developments in photobiomodulation and cancer. Photomed Laser Surg. 2012; 30: 615-616. http://dx.doi.org/10.1089/pho.2012.3374

[6] Santana-Blank L, Rodríguez-Santana E, Santana-Rodríguez JA, Santana-Rodríguez KE. Solid tumors and photobiomodulation: A novel approach to induce physiologically reparative homeostasis / homeokinesis-review. Journal of Solid Tumors. 2012; 2: 23-35. ISSN 1925-4067(Print) ISSN 1925-4075(Online) http://www.sciedu.ca/journal/index.php/jst/article/view/1718/1028;

[7] Prendergast GC. Cancer: Why tumours eat tryptophan.Nature. 2011; 478: 192-194. PMid:21993754 http://dx.doi.org/10.1038/478192a

[8] Santana-Blank L, Rodríguez-Santana E, Santana-Rodríguez KE. Cancer, Warburg Effect and Laser Photobiomodulation Progress Beyond Skepticism. Journal of Chinese Clinical Medicine. 2011; 6: 147-157.

[9] Santana-Blank LA, Rodríguez-Santana E, Vargas F, Reyes H, Fernández-Andrade P, Rukos S, et al. Phase I trial of an infrared pulsed laser device in patients with advanced neoplasias. Clin Cancer Res. 2002; 8: 3082-3091. PMid:12374675

[10] Santana-Blank LA, Rodríguez-Santana E, Vargas F, Santana-Rodríguez KE. Photo-induced cytomorphologic changes in an advanced cancer phase I clinical trial. Lasers Surg Med. 2002; 30: 18-25. http://dx.doi.org/10.1002/lsm.10017

[11] Santana-Blank LA, Reyes H, Rodríguez-Santana E, Santana-Rodríguez KE. Microdensitometry of T2-weighted magnetic resonance (MR) images from patients with advanced neoplasias in a phase I clinical trial of an infrared pulsed laser device (IPLD).Lasers Surg Med. 2004; 34: 398-406. PMid:15216533 http://dx.doi.org/10.1002/lsm.20068 
[12] Santana-Blank LA, Castes M, Rojas ME, Vargas F, Scott-Algara D.Evaluation of serum levels of tumour necrosis factor-alpha (TNF-alpha) and soluble IL-2 receptor (sIL-2R) and CD4, CD8 and natural killer (NK) populations during infrared pulsed laser device (IPLD) treatment. Clin Exp Immunol. 1992; 90: 43-8. PMid:1395099 http://dx.doi.org/10.1111/j.1365-2249.1992.tb05829.x

[13] McGuff PE, Deterling RA Jr, Gottlieb LS, Fahimi HD, Bushnell D, Roebert F. The Laser Treatment of Experimental Malignant Tumours' Canad. Med. Ass. J. 1964; 91: 1089-1095.

[14] McGuff PE, Deterling RA Jr, Gottlieb LS. Tumoricidal Effect of Laser Energy on Experimental and Human Malignant Tumors. N Engl J Med 1965; 273: 490-492. PMid:5318702 http://dx.doi.org/10.1056/NEJM196508262730906

[15] Hamblin MR. Mechanisms of low level light therapy”, Proc. SPIE. 2006; 6140: 1-12. http://dx.doi.org/10.1117/12.646294

[16] Karu TI. Mitochondrial signaling in mammalian cells activated by red and near-IR radiation. Photochem and Photobiol. 2008; 84: 1091-1099. PMid:18651871 http://dx.doi.org/10.1111/j.1751-1097.2008.00394.x

[17] Hamblin MR. Introduction to experimental and clinical studies using low-level laser (light) therapy (LLLT). Lasers Surg Med. 2010; 42: 447-449. PMid:20662020 http://dx.doi.org/10.1002/1sm.20959

[18] Peplow PV, Chung T-Y, Baxter GD. Laser Photobiomodulation of Proliferation of Cells in Culture: A Review of Human and Animal Studies. Photomedicine and Laser Surgery. 2010; 28: S-3-S-40. PMid:20666617 http://dx.doi.org/10.1089/pho.2010.2771

[19] Warburg O, Wind F, Negelein E. The Metabolism of Tumors in The Body. J Gen Physiol. 1927; 8: 519-30. PMid:19872213 http://dx.doi.org/10.1085/jgp.8.6.519

[20] Vander Heiden MG, Cantley L C, Thompson CB. Understanding the Warburg effect: the metabolic requirements of cell proliferation. Science. 2009; 324: 1029-33. PMid:19460998 http://dx.doi.org/10.1126/science.1160809

[21] Moncada S, Erusalimsky JD. Does nitric oxide modulate mitochondrial energy generation and apoptosis? Nat Rev Mol Cell Biol. 2002; 3: 214-220. PMid:11994742 http://dx.doi.org/10.1038/nrm762

[22] Almeida A, Bolaños JP, Moncada S. E3 ubiquitin ligase APC/C-Cdh1 accounts for the Warburg effect by linking glycolysis to cell proliferation. Proc Natl Acad Sci U SA. 2010; 107: 738-741. PMid:20080744 http://dx.doi.org/10.1073/pnas.0913668107

[23] Ying L, Hofseth LJ. An emerging role for endothelial nitric oxide synthase in chronic inflammation and cancer. Cancer Res. 2007; 67: 1407-1410. PMid:17308075 http://dx.doi.org/10.1158/0008-5472.CAN-06-2149

[24] Lubart R, Lavi P R, Friedmann H, Rochkind S.Photochemistry and Photobiology of light absorption by living cells. Photomed Laser Surg. 2006; 24: 179-185 PMid:16706696 http://dx.doi.org/10.1089/pho.2006.24.179

[25] Tata DB, Waynant RW. Laser therapy: A review of its mechanism of action and potential medical applications. Laser \& Photonics Review. 2011; 5: 1-12. http://dx.doi.org/10.1002/lpor.200900032

[26] Karu T. Primary and secondary mechanisms of action of visible to near-IR radiation on cells. J Photochem Photobiol B. 1999; 49: 1-17. http://dx.doi.org/10.1016/S1011-1344(98)00219-X

[27] Hamblin MR, Demidova TN. Mechanisms for Low-Light Therapy. Proc.SPIE. 2006; 6140: 614001-614005. http://dx.doi.org/10.1117/12.646294

[28] Santana-Blank LA, Rodríguez-Santana E. Physiologic rhythms responding to low-level electromagnetic and mechanical signals: the Joule equivalence principle. "Photomed Laser Surg. 2008; 26: 405-406. PMid:18647096 http://dx.doi.org/10.1089/pho.2008.2276

[29] Beauvoit B, Kitai T, Chance B. Contribution of the mitochondrial compartment to the optical properties of the rat liver: a theoretical and practical approach. Biophys J. 1994; 67: 2501-2510. http://dx.doi.org/10.1016/S0006-3495(94)80740-4

[30] Santana-Blank L, Rodríguez-Santana E, Santana-Rodríguez K.E. Theoretic, Experimental, Clinical Bases of the Water Oscillator Hypothesis in Near-Infrared Photobiomodulation. Photomed Laser Surg Suppl. 2010; 28: 41.

[31] Santana-Blank LA, Rodríguez-Santana E, Santana-Rodríguez KE. Photo-infrared pulsed bio-modulation (PIPBM): a novel mechanism for the enhancement of physiologically reparative responses. Photomed Laser Surg. 2005; 23: 416-24.

PMid:16144487 http://dx.doi.org/10.1089/pho.2005.23.416

[32] Khakh BS. North RA. P2X receptors as cell-surface ATP sensors in health and disease. Nature. 2006; 442: $527-532$. PMid:16885977 http://dx.doi.org/10.1038/nature04886

[33] Barth K, Kasper M. Membrane compartments and purinergic signalling: occurrence and function of P2X receptors in lung. FEBS J. 2009; 276: 341-353. PMid:19076210 http://dx.doi.org/10.1111/j.1742-4658.2008.06795.x

[34] Rapaport E, Fishman RF, Gercel C. Growth inhibition of human tumor cells in soft-agar cultures by treatment with low levels of adenosine 5'-triphosphate. Cancer Res. 1983; 43: 4402-4406. PMid:6871873

[35] Rapaport E. Treatment of human tumor cells with ADP or ATP yields arrest of growth in the S phase of the cell cycle. J Cell Physiol. 1983; 114: 279-283. PMid:6833403 http://dx.doi.org/10.1002/jcp.1041140305

[36] Khakh BS, Burnstock G. The Double Life of ATP. Sci Am. 2009; 301: 90-92. 
http://dx.doi.org/10.1038/scientificamerican1209-84

[37] Geschwind JF, Ko YH, Torbenson MS, Magee C, Pedersen PL. Novel therapy for liver cancer: direct intraarterial injection of a potent inhibitor of ATP production. Cancer Res. 2002; 62: 3909-3913. PMid:12124317

[38] Deli T, Csernoch L. Extracellular ATP and cancer: an overview with special reference to P2 purinergic receptors. Pathol Oncol Res. 2008; 14: 219-231. PMid:18575829 http://dx.doi.org/10.1007/s12253-008-9071-7

[39] Shin YK, Yoo BC, Chang HJ, Jeon E, Hong SH, Jung MS, et al. Down-regulation of mitochondrial F1F0-ATP synthase in human colon cancer cells with induced 5-fluorouracil resistance. Cancer Res. 2005; 65: 3162-3170. PMid:15833846

[40] Wang GG, Allis CD, Chi P. Chromatin remodeling and cancer, Part II: ATP-dependent chromatin remodeling. Trends Mol Med. 2007; 13: 373-380. PMid:17822959 http://dx.doi.org/10.1016/j.molmed.2007.07.004

[41] Cuezva JM, Krajewska M, de Heredia ML, Krajewski S, Santamaría G, Kim H, et al. The bioenergetic signature of cancer: a marker of tumor progression. Cancer Res. 2002; 62: 6674-6681. PMid:12438266

[42] Astumian RD. Making molecules into motors. Sci Am. 2001; 285: 56-64. PMid:11432195 http://dx.doi.org/10.1038/scientificamerican0701-56

[43] Bland ML, Birnbaum MJ. Cell biology. ADaPting to energetic stress. Science. 2011; 332: 1387-1388. PMid:21680830 http://dx.doi.org/10.1126/science. 1208444

[44] Khakh BS, North RA. P2X receptors as cell-surface ATP sensors in health and disease. Nature. 2006; 442: 527-532.PMid:16885977 http://dx.doi.org/10.1038/nature04886

[45] Barth K, Kasper M. Membrane compartments and purinergic signalling: occurrence and function of P2X receptors in lung. FEBS J. 2009; 276: 341-353. PMid:19076210 http://dx.doi.org/10.1111/j.1742-4658.2008.06795.x

[46] Rapaport E. Treatment of human tumor cells with ADP or ATP yields arrest of growth in the S phase of the cell cycle. J. Cell. Physiol. 1983; 114: 279-283. PMid:6833403 http://dx.doi.org/10.1002/jcp.1041140305

[47] Rapaport E, Fishman RF, Gercel C. Growth inhibition of human tumor cells in soft-agar cultures by treatment with low levels of adenosine 5' triphosphate.Cancer Res. 1983; 43: 4402-4406. PMid: 6871873

[48] Khakh BS, Burnstock G.The double life of ATP. Sci Am. 2009; 301: 84-90, 92. PMid:20058644 http://dx.doi.org/10.1038/scientificamerican1209-84

[49] Faubert B, Boily G, Izreig S, Griss T, Samborska B, Dong Z, et al. AMPK Is a Negative Regulator of the Warburg Effect and Suppresses Tumor Growth In Vivo. Cell Metab. 2013; 17: 113-24. http://dx.doi.org/10.1016/j.cmet.2012.12.001

[50] Karu T. Mitochondrial mechanisms of photobiomodulation in context of new data about multiple roles of ATP. Photomed Laser Surg. 2010; 28: 159-160. PMid:20374017 http://dx.doi.org/10.1089/pho.2010.2789

[51] Sommer AP, Caron A, Fecht HJ. Tuning nanoscopic water layers on hydrophobic and hydrophilic surfaces with laser light. Langmuir. 2008; 24: 635- 636. http://dx.doi.org/10.1021/la7032737

[52] Karu T, Pyatibrat LV, Kolyakov SV, Afanasyeva NI. Absorption measurements of cell monolayers relevant to mechanisms of laser phototherapy: reduction or oxidation of cytochrome c oxidase under laser radiation at $632.8 \mathrm{~nm}$. Photomed Laser Surg. 2008; 26: 593-599. PMid:19099388 http://dx.doi.org/10.1089/pho.2008.2246

[53] Eells JT, Wong-Riley MT, VerHoeve J, Henry M, Buchman EV, Kane MP, et al. Mitochondrial signal transduction in accelerated wound and retinal healing by near-infrared light therapy. Mitochondrion. 2004; 4: 559-567. PMid:16120414 http://dx.doi.org/10.1016/j.mito.2004.07.033

[54] Karu TI, Pyatibrat LV, Afanasyeva NI. A novel mitochondrial signaling pathway activated by visible-to-near infrared radiation. Photochem Photobiol. 2004; 80: 366-372. PMid:15362946 http://dx.doi.org/10.1562/2004-03-25-RA-123.1

[55] Zhang Y, Song S, Fong CC, Tsang CH, Yang Z, Yang M. cDNA microarray analysis of gene expression profiles in human fibroblast cells irradiated with red light. J Invest Dermatol. 2003; 120: 849-57. PMid:12713592 http://dx.doi.org/10.1046/j.1523-1747.2003.12133.x

[56] Masha RT, Houreld NN, Abrahamse H. Low-Intensity Laser Irradiation at $660 \mathrm{~nm}$ Stimulates Transcription of Genes Involved in the Electron Transport Chain. Photomed Laser Surg. 2013; 31: 47-53. http://dx.doi.org/10.1089/pho.2012.3369

[57] Santana-Blank L, Rodríguez-Santana E. The interaction of light with nanoscopic layers of water may be essential to the future of photobiomodulation. Photomed Laser Surg. Suppl. 2010; 1: 173.

[58] Gonzalez J A, Martin-Landrove. M. Solitons in a nonlinear DNA model. Physics Letters A. 1994; 191: 409-415. http://dx.doi.org/10.1016/j.bbr.2011.03.031

[59] Gonzalez J A, Martin-Landrove M, Carbo JR, Chacon M. Bifurcations and Chaos of DNA Solitonic Dynamics. International Centre for Theoretical Physics, ed., Trieste, Italy: International Atomic Energy Agency and United Nations Educational Scientific and Cultural Organization. 1994; IC/94/301: 1-31. 
[60] Santana-Blank, LA, Rodriguez-Santana E, Scott-Algara D, Hunger M, Santana-Rodriguez KE, Orellana R. Short-term bioeffects of an infrared pulsed laser device on burned rat skin monitored by transverse relaxation times (NMR). Lasers Surg. Med. 2000; 27 : 411-419. http://dx.doi.org/10.1002/1096-9101(2000)27:5<411::AID-LSM1002>3.0.CO;2-P

[61] Rodríguez-Santana E, Santana-Blank LA, Reyes H, Santana-Rodríguez KE, Hunger M, Orellana R, et al. H-NMR spin-lattice and correlation times of burned soft-tissues after treatment with an infrared pulsed laser device. Lasers Surg Med. 2003; 33: 190-198. PMid:12949949 http://dx.doi.org/10.1002/1sm.10209

[62] Santana-Blank US Patent $N^{\circ}$ 5, 231,984 and other global patents [Internet]. Available from: http://www.google.com/patents/US5231984

[63] Martín, R, Martín-Landrove, M. A novel algorithm for tumor characterization by analysis of transversal relaxation rate distributions in MRI. In Spatially Resolved Magnetic Resonance, ed. Weinheim: Wiley-VCH. 1998; 133-138.

[64] Martín M, Itriago S, Martín R, Santana-Blank LA. In Proceeding of the Applied Spectroscopy Nuclear Magnetic Resonance Conference Commemorating the 50th Anniversary of NMR: 26-30 March 1995; Boston [Internet]. Edited by Hellmut Eckert: ENC, 1995: 25. Available from: https:/www.enc-conference.org/files/enc\%201995.pdf

[65] Israelsen WJ, Vander Heiden MG. ATP consumption promotes cancer metabolism. Cell. 2010; 143: 669-671. PMid:21111226 http://dx.doi.org/10.1016/j.cell.2010.11.010

[66] Aarntzen EH, De Vries IJ, Lesterhuis WJ, Schuurhuis D, Jacobs JF, Bol K, et al. Targeting CD4+ T-Helper Cells Improves the Induction of Antitumor Responses in Dendritic Cell-Based Vaccination. Cancer Res. 2013; 73: 19-29. http://dx.doi.org/10.1158/0008-5472.CAN-12-1127

[67] Le Campion A, Pommier A, Delpoux A, Stouvenel L, Auffray C, Martin B, et al. IL-2 and IL-7 Determine the Homeostatic Balance between the Regulatory and Conventional CD4 ${ }^{+} \mathrm{T}$ Cell Compartments during Peripheral T Cell Reconstitution. J Immunol. 2012; 189: 3339-3346. PMid:22933631 http://dx.doi.org/10.4049/jimmunol.1103152

[68] Coussens LM, Zitvogel L, Palucka AK. Neutralizing Tumor-Promoting Chronic Inflammation: A Magic Bullet? Science. 2013; 339: 286-91. http://dx.doi.org/10.1126/science.1232227

[69] Balakirev SA, Gusev LI, Kazanova MB, Kiselevskiǔ MV, Grabovshchiner AIa. Low-intensity laser therapy in pediatric oncology (Article in Russian). Voprosy onkologii. 2000; 46: 459-461. PMid:11147426

[70] Zimin AA, Zhevago NA, Buĭniakova AI, Samoĭlova KA. Application of low-power visible and near infrared radiation in clinical oncology.Vopr Kurortol Fizioter Lech Fiz Kult. 2009; 6: 49-52. [Article in Russian]

[71] Zhang Y, Song S, Fong CC, Tsang CH, Yang Z, Yang M. (2003) cDNA microarray analysis of gene expression profiles in human fibroblast cells irradiated with red light. J Invest Dermatol. 2003; 120: 849-57. PMid:12713592 http://dx.doi.org/10.1046/j.1523-1747.2003.12133.x

[72] Lane N. Cell biology: power games. Nature. 2006; 443: 901-903. PMid:17066004 http://dx.doi.org/10.1038/443901a

[73] Dong-Liang R,Cheng-Yi, Liu T, Hua J. Photobiomodulation on tumor cells in vitro and tumor tissue in vivo. Proc. SPIE. 2006; 6026E: ICO20. http://dx.doi.org/10.1117/12.667111

[74] Wang F, Chen TS, Xing D, Wang JJ, Wu YX. Measuring dynamics of caspase-3 activity in living cells using FRET technique during apoptosis induced by high fluence low-power laser irradiation. Lasers Surg Med. 2005; 36: 2-7. PMid:15662635 http://dx.doi.org/10.1002/1sm.20130

[75] Tanaka Y, Matsuo K, Yuzuriha S, Yan H, Nakayama J. Non-thermal cytocidal effect of infrared irradiation on cultured cancer cells using specialized device. Cancer Science. 2010; 101: 1396-1402. PMid:20345484 http://dx.doi.org/10.1111/j.1349-7006.2010.01548.x

[76] Myakishev-Rempel M, Stadler I, Brondon P, Axe DR, Friedman M, Nardia FB, et al. A preliminary study of the safety of red light phototherapy of tissues harboring cancer. Photomed Laser Surg. 2012; 30: 551-8. http://dx.doi.org/10.1089/pho.2011.3186

[77] Tata DB, Fahey M, Mitra K, Anders J, Waynant RW. Near-IR induced suppression of metabolic activity in aggressive cancers. Proc. SPIE. 2007; 6428: 64280E. http://dx.doi.org/10.1117/12.699120

[78] Tata DB, Waynant RW. Laser light induced modulations in metabolic activities in human brain cancer. Proc. SPIE. 2008; 6846: 684607. http://dx.doi.org/10.1117/12.763526

[79] Tata DB, Waynant RW. A comparative study on non-confluent and confluent human malignant brain cancer metabolic response to He-Ne laser exposures: evidence for laser enhanced cellular production of $\mathrm{H}_{2} \mathrm{O}_{2}$ and laser induced bystander effect. Proc. SPIE. 2009; 7165: 716508. http://dx.doi.org/10.1117/12.813409

[80] Santana-Blank L. Contraindications in noninvasive laser therapy: truth and fiction. Photomed Laser Surg. 2004; 22: 442. Author reply 442 .

[81] Burnstock G. Physiology and pathophysiology of purinergic neurotransmission. Physiol Rev. 2007; 87: 659-797. PMid:17429044 http://dx.doi.org/10.1152/physrev.00043.2006 
[82] Shabbir M, Ryten M, Thompson C, Mikhailidis D, Burnstock G. Purinergic receptor-mediated effects of ATP in high-grade bladder cancer. BJU Int. 2008; 101: 106-112. PMid:17941929

[83] Wentworth AD, Jones LH, Wentworth P, Janda KD, Lerner RA. Antibodies have intrinsic capacity to destroy antigens. Proc. Natl. Acad. Sci. USA. 2000; 97: 10930-10935. PMid:11005865 http://dx.doi.org/10.1073/pnas.97.20.10930

[84] Chen A C-H, Praveen R, Arany PR, Huang Y-Y, Tomkinson EM, Saleem T, et al. Low level laser therapy activates NF-kB via generation of reactive oxygen species in mouse embryonic fibroblasts. Proc SPIE. 2009; 7165: 71650B. http://dx.doi.org/10.1117/12.809605

[85] Andersen V, Christensen J, Overvad K, Tjønneland A, Vogel U. Polymorphisms in NFkB, PXR, LXR and risk of colorectal cancer in a prospective study of Danes. BMC Cancer. 2010; 10: 484. PMid:20836841 http://dx.doi.org/10.1186/1471-2407-10-484

[86] Sankar Ghosh. Handbook of Transcription Factor NF-kappaB [Internet]. Boca Raton: CRC Press. Taylor \& Francis Group. 2007; 9-24. Available from: http:/www.crenetbase.com/doi/pdf/10.1201/9781420004274.fmatt

[87] Dong-Liang R, Timon Cheng-Yi Liu, Hua J. Photobiomodulation on tumor cells in vitro and tumor tissue in vivo. Proc. SPIE. 2006; 6026: 60260E.

[88] Liu YH, Cheng CC, Ho CC, Pei RJ, Lee KY, Yeh KT, Chan Y, Lai YS.Effects of diode 808 nm GaAlAs low-power laser irradiation on inhibition of the proliferation of human hepatoma cells in vitro and their possible mechanism. Res Commun Mol Pathol Pharmacol. 2004; 115-116: 185-201. PMid:17564317

[89] Sommer AP, Zhu D, Scharnweber T. Laser modulated transmembrane convection: Implementation in cancer chemotherapy. J Control Release. 2010; 148: 131-134. PMid:20934473 http://dx.doi.org/10.1016/j.jconrel.2010.10.010

[90] Pinheiro AL, Carneiro NS, Vieira AL, Brugnera A Jr, Zanin FA, Barros RA, et al. Effects of low-level laser therapy on malignant cells: in vitro study. Journal of clinical laser medicine \& surgery. 2002; 20: 23-26. PMid:11902350 http://dx.doi.org/10.1089/104454702753474977

[91] Frigo L, Luppi JS, Favero GM, Maria DA, Penna SC, Bjordal JM, et al. The effect of low-level laser irradiation (In-Ga-Al-AsP $660 \mathrm{~nm}$ ) on melanoma in vitro and in vivo. BMC Cancer. 2009; 20: 404 . PMid:19930543 http://dx.doi.org/10.1186/1471-2407-9-404

[92] Carati CJ, Anderson SN, Gannon BJ, Piller NB.Treatment of postmastectomy lymphedema with low-level laser therapy: a double blind, placebo-controlled trial. Cancer. 2003; 98: 1114-1122. PMid:12973834 http://dx.doi.org/10.1002/cncr.11641

[93] Omar MT, Shaheen AA, Zafar H.A systematic review of the effect of low-level laser therapy in the management of breast cancer-related lymphedema. Support Care Cancer. 2012; 20: 2977-84. http://dx.doi.org/10.1007/s00520-012-1546-0

[94] Castro G, de Lima A G, Lopes DR, Ortegosa MV, Rosalmeida MC, Gil E, et al. Oral mucositis prevention by low-level laser therapy in head and neck cancer patients submitted to concurrent chemoradiation: A prospective randomized study. J Clin Oncol Supp. 2009; 27: 6019.

[95] Migliorati C, Hewson I, Lalla RV, Antunes HS, Estilo CL, Hodgson B, et al. Mucositis Study Group of the Multinational Association of Supportive Care in Cancer/International Society of Oral Oncology (MASCC/ISOO). Systematic review of laser and other light therapy for the management of oral mucositis in cancer patients. Support Care Cancer. 2013; $21: 333-41$. http://dx.doi.org/10.1007/s00520-012-1605-6

[96] Gautam AP, Fernandes DJ, Vidyasagar MS, Maiya AG, Nigudgi S. Effect of low-level laser therapy on patient reported measures of oral mucositis and quality of life in head and neck cancer patients receiving chemoradiotherapy-a randomized controlled trial. Support Care Cancer. 2012. [Epub ahead of print]

[97] Nes AG, Posso MB. Patients with moderate chemotherapy-induced mucositis: pain therapy using low intensity lasers. Int Nurs Rev. 2005; 52:68-72. PMid:15725279 http://dx.doi.org/10.1111/j.1466-7657.2004.00401.x

[98] van Coevorden RS. The Low Level Laser in Palliative Care. Adv. Pall. Med. 2009; 8: 83-88.

[99] Bensadoun RJ, Nair RG. Low-level laser therapy in the prevention and treatment of cancer therapy-induced mucositis: 2012 state of the art based on literature review and meta-analysis. Curr Opin Oncol. 2012; 24: 363-70. http://dx.doi.org/10.1097/CCO.0b013e328352eaa3

[100] Santana-Blank L, Rodríguez-Santana E, Santana-Rodríguez KE. Photobiomodulation of aqueous interfaces as selective rechargeable bio-batteries in complex diseases: personal view. Photomed Laser Surg. 2012; 30: 242-9. http://dx.doi.org/10.1089/pho.2011.3123 